UDK $630 * 32: 658.53(497.6$ Olovo)

\title{
ANALYSIS OF TIME CONSUMPTION DURING SESSILE OAK FELLING AND PROCESSING WORKS APPLYING THE FULL-LENGTH METHOD
}

\author{
Analiza utroška vremena pri sječi i izradi stabala hrasta kitnjaka primjenom deblovnog \\ metoda rada \\ Velid Halilović $^{1}$, Safet Gurda ${ }^{1}$, Jusuf Musić ${ }^{1}$, Dževada Sokolović ${ }^{1}$, Muhamed Bajrić ${ }^{1}$, Jelena \\ Knežević ${ }^{1}$, Anđelko Brnić ${ }^{2}$
}

\begin{abstract}
This paper presents an analysis of full-length method used in the phase of sessile oak felling and sorting works. The aim of the research was to establish time consumption during sessile oak felling and sorting works using full-length processing method. The research was conducted in the area managed by Forest enterprise "Šumsko - privredno društvo Zeničko-dobojskog kantona" Zavidovići, Management unit "Šumarija" Olovo, Forest unit "Krivaja", compartment 112. The sampling method was applied for measuring time consumption of work operations. It was established that the share of effective time in total time was $67.12 \%$, the share of unavoidable delay times was $30.79 \%$, and the share of avoidable delay times was $2.09 \%$. Time consumption of tree felling and processing was strongly affected from tree diameter at the breast height $\left(\mathrm{R}^{2}=0.656\right)$. The achieved results will be used for further research on this topic, which has been unduly neglected in the past few years in the BH forestry. Further research would certainly include ergonomics, economy of work procedures, occupational safety and environmental consequences of forestry work.
\end{abstract}

Key words: tree felling and sorting works, time and work study method, full-length method.

\section{INTRODUCTION - Uvod}

The selection of methods and means of work in forest exploitation largely depends on a various number of field and stand factors. Out of the many known work methods (assortment, full-length, half-length, chipping and cut-to-length method) the following methods are also applied in Bosnia and Herzegovina forestry: assortment and half/full-length method, while the application of stem method is illegal. This analysis focuses on the full-length method of sessile oak assortment felling and processing works. The method is defined by the number and type of operations, as well as spatial and temporal schedule. The full-length method includes the collection of data for felling and processing.

The selection of methods and means of work in forest exploitation presents a significant problem. Considering the work field conditions in $\mathrm{BiH}$, the application of

${ }^{1}$ Faculty of Forestry, University of Sarajevo, Bosnia and Herzegovina.

2 „Hercegbosanske šume“ d.o.o. Kupres, Bosnia and Herzegovina. 
the full-length method can be one of the solutions for a better exploitation of less valuable wood assortments.

Technological research using the chronometric method, as part of the time and work study method, makes it possible to ascertain the structure of work time, and the regression analysis of data gives the strength of the influence of single factors while cutting and processing logs.

Most authors (BOJANIN, 1974, 1978; HÄBERLE, 1961; KRALJIĆ, 1974; TOMANIĆ, 1975; HALILOVIĆ, 2012) used the method of temporary observation in their research.

KULUŠIĆ and MIODRAGOVIĆ (1979) conducted the research on the technological processes of felling and processing, extracting pine and oak wood, ascertain the effects and productivity of work for the projected technologies of work.

JOVANOVIĆ, (1980) conducted the research on the time spent for two technologies of work in forest exploitation, i.e. assortment and full-length method during exploitation, with the application of temporary observation.

BOJANIN et al (1989) conducted the research on the comparison of felling and processing wood assortments in the stands of the common oak and black alder. The assortment method was applied, with the production of assortments of technical roundwood and several meter-long industrial wood of loading lengths being produced in the stands.

The application of the assortment, full-length and half-length method along the tree felling using the chain saw in different conditions was researched by BOJANIN and KRPAN (1994), where a whole-day study of work was conducted with the application of chronometrics, with the duration of 24 days in the hills and 59 days in the valleys.

BOJANIN and KRPAN (1997) researched the extraction the round technical and industrial wood of loading lengths in tall one-season broadleaved forests, where the assortment, full-length and half-length method was applied.

DANILOVIĆ and OBUĆINA (2006) conducted the comparison of two methods of felling and processing forest assortments in poplar stands. The comparison included the harvester and the conventional method of felling and processing forest assortments.

HALILOVIĆ et al (2013) also worked on researching the time spent on felling and processing sessile oak trees in the same area with the application of the assortment work method.

With the aim of using the full-length method, an area was selected where all the phases of working on felling and processing wood were recorded. The conducted research is connected to the system of shelterwood and is consistent with this management and the applied full-length method of felling and processing wood at the stump. 


\section{RESEARCH GOAL - Cilj istraživanja}

The aim of the research was to ascertain the time spent on sessile oak felling and processing using the full-length work method. Through detailed measurements of time spent of individual operations in the phases of felling and processing with the chain saw it was intended to reach the data on the participation of certain operations in this phase.

\section{MATERIAL AND METHODS - Materijal i metode}

The research was conducted in the area managed by Forest enterprise of the Zenica-Doboj Canton d.o.o. Zavidovići, Management unit "Šumarija" Olovo, compartment 112 .

Data collection was conducted on 495 sessile oak trees using necessary recording equipment such as recording board, stop watch, tape and diameter measure. The work sampling method was applied for measuring time consumption of working operations with an observation interval of 20 seconds. The data for every felled tree was registered into an appropriate form. Working organization $1+1$ was applied (cutter and assistant worker).

Determination of the volume of the tree was conducted based on the length and the average diameter at the middle point of the length of the tree.

The field recording was conducted in the winter period, during the months of December 2010 and January 2011.

The program Statistica 7 was used for statistical data processing and the rendering of appropriate charts and equations with their coefficients.

\section{RESULTS - Rezultati}

\section{The structure of felled and processed wood}

During the tree-length work method, data has been collected for all work operations regarding the felling and processing phase. The average wood volume was gained from the measurements of the basic data on the trees (table 1).

Table 1. The structure of felled and processed wood

Tabela 1: Struktura posječene i izrađene drvne mase

\begin{tabular}{|c|c|c|c|c|c|c|c|}
\hline $\begin{array}{c}\text { Number } \\
\text { of trees }\end{array}$ & \multicolumn{2}{|c|}{$\begin{array}{c}\text { Diameter at the breast height } \\
(\mathrm{cm})\end{array}$} & $\begin{array}{c}\text { Tree } \\
\text { height }(\mathrm{m})\end{array}$ & \multicolumn{3}{c|}{ Net volume of felled trees $\left(\mathrm{m}^{3}\right)$} \\
\hline Piece & Maximum & Minimum & Average & Average & $\begin{array}{c}\text { Technical } \\
\text { roundwood }\end{array}$ & Fuelwood & Total \\
\hline 495 & 61 & 10 & 28.18 & 18.55 & 201.23 & 181.54 & 382.77 \\
\hline
\end{tabular}

It is easily noticeable from the table that fuelwood takes a large part in the net volume of felled trees. The share of fuelwood was $47.43 \%\left(181.54 \mathrm{~m}^{3}\right)$, and technical roundwood $52.57 \%\left(201.23 \mathrm{~m}^{3}\right)$. 


\section{The structure of time consumption of felling and processing of wood}

The recorded time showed the structure of total work time (Chart 1). Effective (operational) time is $67.12 \%$ of total work time, unavoidable delay time is $30.79 \%$, and avoidable delay time is $2.09 \%$.

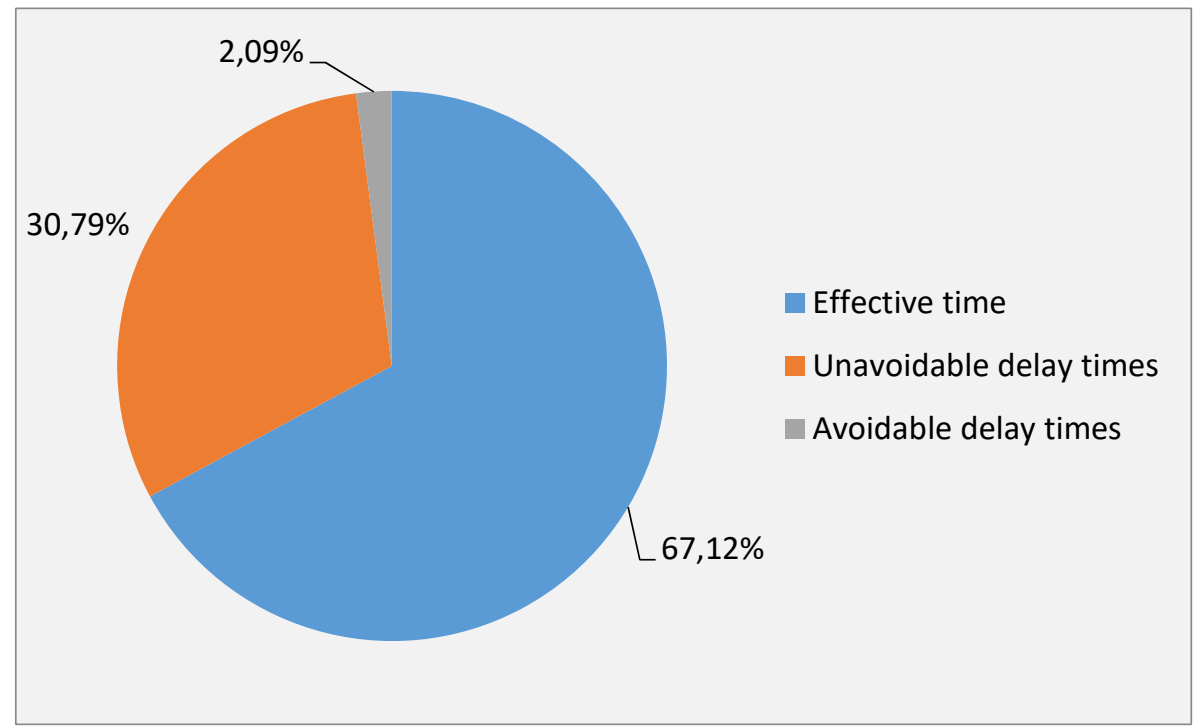

Chart 1. The structure of total work time

Grafikon 1. Struktura ukupnog radnog vremena

The structure of effective (operational) time consists of the time for individual work operations in the entire phase of felling and processing. The percentage of the individual operations times is presented in $\mathrm{t}$ able 2 , while the percentage share of these times in relation to the total operational time is presented in chart 2.

Table 2. The share of effective time in total time

Tabela 2. Udio operativnog vremena u ukupnom vremenu

\begin{tabular}{|c|l|c|}
\hline $\begin{array}{c}\text { Ordinal } \\
\text { number }\end{array}$ & \multicolumn{1}{|c|}{ Working operation } & $\begin{array}{c}\text { The share in } \\
\text { total time (\%) }\end{array}$ \\
\hline 1. & Moving to tree & 7.58 \\
\hline 2. & Preparation of the workplace & 3.75 \\
\hline 3. & Tree cutting & 8.46 \\
\hline 4. & Releasing lodged trees & 2.50 \\
\hline 5. & Delimbing & 31.78 \\
\hline 6. & Processing the tree top & 0.37 \\
\hline 7. & Forest residues management & 10.57 \\
\hline 8. & Wood fiber cutting on a felled tree & 2.11 \\
\hline & Total: & 67.12 \\
\hline
\end{tabular}




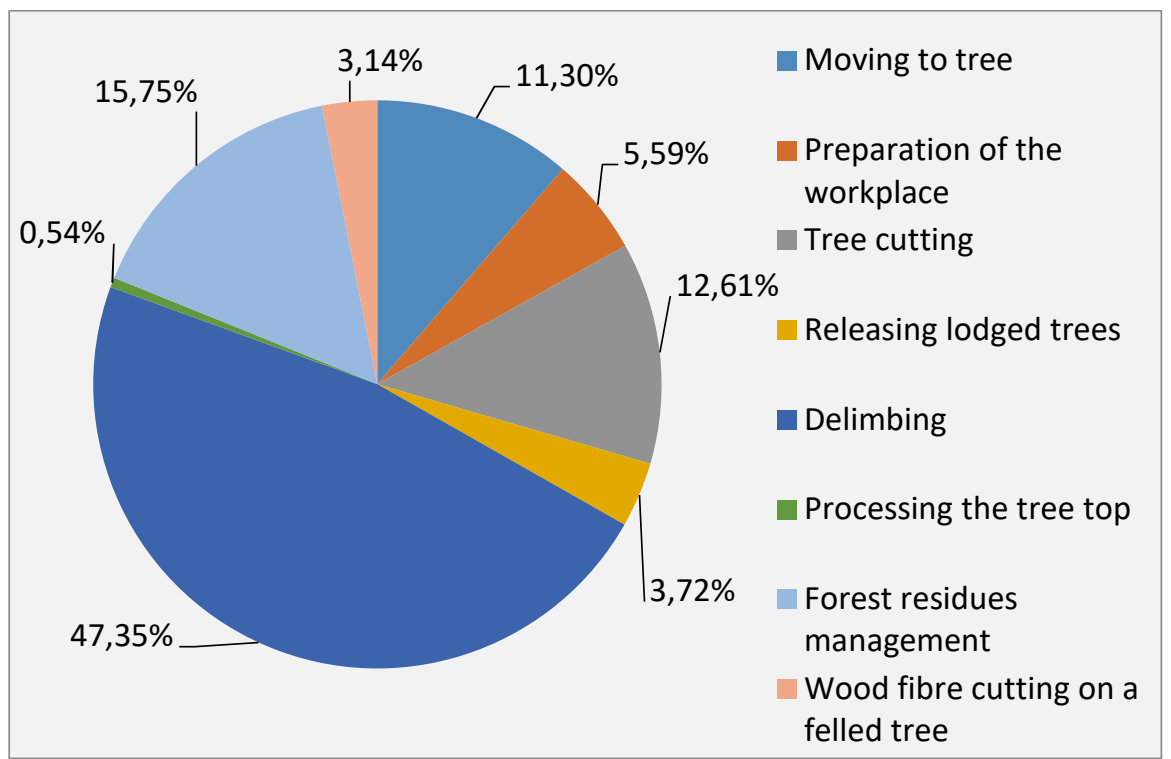

Chart 2. The structure of effective time

Grafikon 2. Struktura operativnog vremena

\section{Moving from tree to tree}

This operation takes a share of $7.58 \%$ of total time, while in effective time the share is $11.3 \%$. The average time of moving from tree to tree is: $t_{\text {move }}=0,69 \pm 0,51$ minute/tree.

\section{Log time - preparation of the workplace}

As part of log time there is time for preparing the workplace, tree cutting, releasing lodged trees, delimbing and forest residues management.

\section{Preparation of the workplace}

The conducted regression analysis showed that under equal working conditions, the duration of this work operation largely depends on the breast diameter of the tree $\left(\mathrm{R}^{2}=564\right)$.

Graph 3 presents the tested dependency and is expressed with the following equation:

$\mathrm{t}_{\text {preparation }}=0,2153-0,0144 \times D_{1,30}+0,0005 \times D_{1,30}{ }^{2}$ minute/tree. For this work phase it is evident that the larger the diameter of the tree the more time is spent preparing the workplace. 


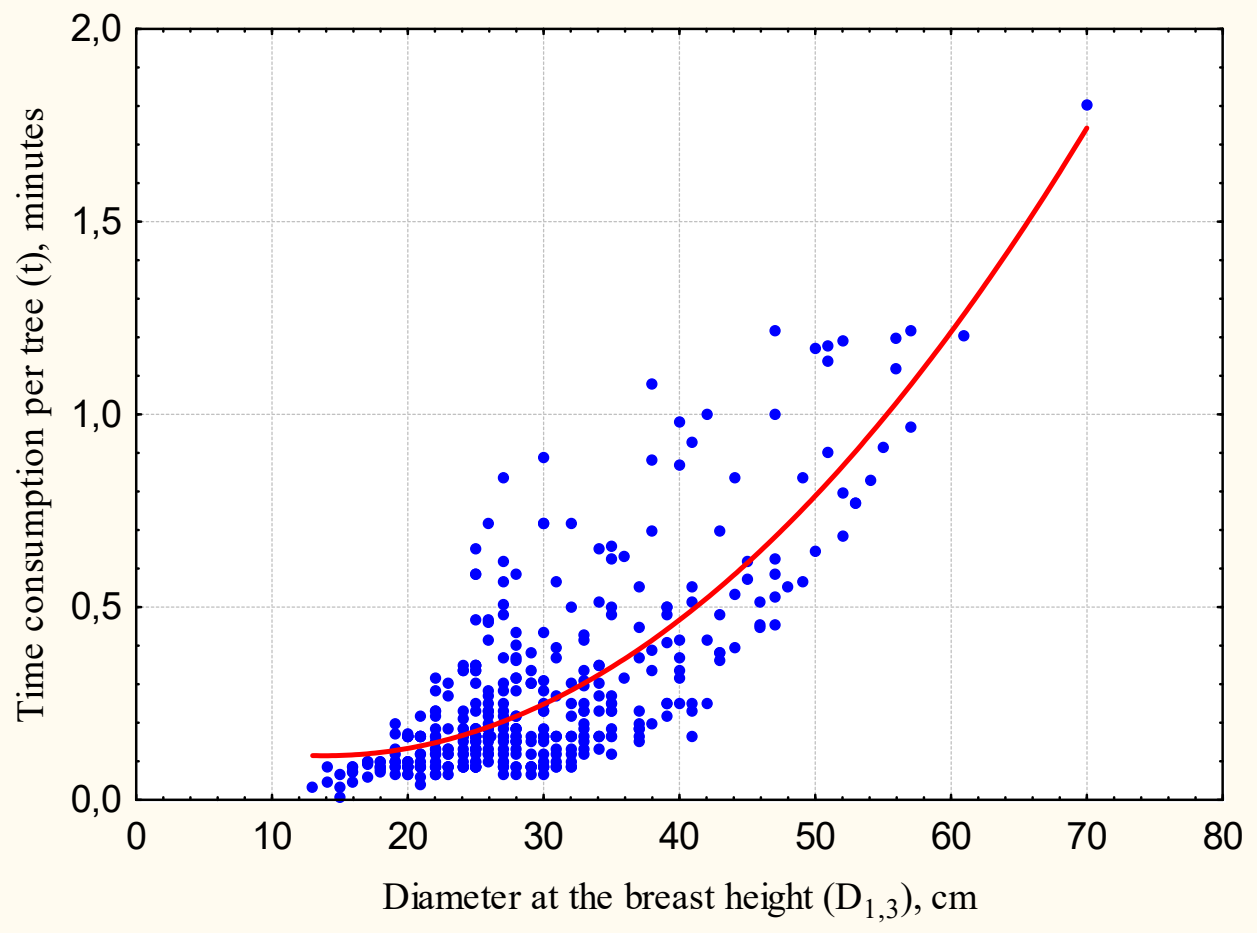

Graph 3. Time consumption of preparing of workplace, minutes per tree Grafikon 3. Utrošak radnog vremena za pripremu radnog mjesta, minuta/stablu

\section{Tree cutting}

The regression analysis showed that there is a statistically significant difference in the consumption of time related to the breast diameter of the tree, where the regression coefficient was $R^{2}=0,563$. This statistical dependency is expressed through a second-degree polynomial:

$\mathrm{t}_{\text {cutting }}=0,3308-0,0176 \times D_{1,30}+0,0008 \times D_{1,30}{ }^{2}$ and is presented on the Chart 4 . It is evident from the chart that by increasing the breast diameter, the time for cutting the tree increases as well. 


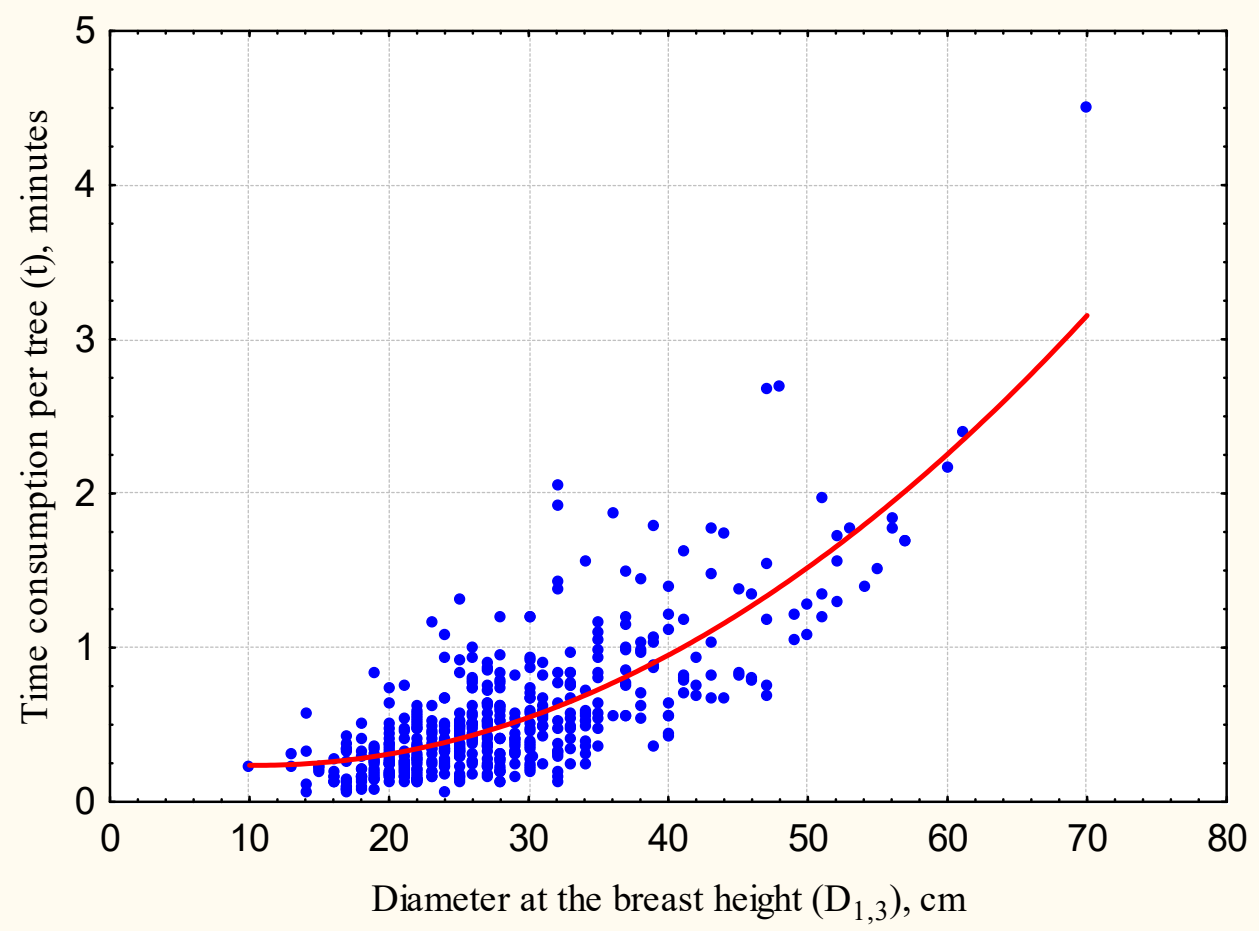

Graph 4. Time consumption of tree cutting, minutes per tree

Grafikon 4. Utrošak radnog vremena za rušenje stabla, minuta/stablu

\section{Releasing lodged trees}

When this work phase is considered it was presented the average value as follows: $t_{\text {release }}=2,13 \pm 1,35$ minute/tree.

\section{Delimbing}

The analysis confirmed that there is a significant difference in delimbing dependence of the breast diameter, and that the regression coefficient in this case is: $R^{2}=0,606$ for the significance level of $5 \%$. The above-mentioned data are presented with the equation:

$\mathrm{t}_{\text {delimbing }}=0,3340-0,0141 \times D_{1,30}+0,0024 \times D_{1,30}{ }^{2}$, and presented in Graph 5 .

The chart evidently presents the fact that by increasing the breast diameter of the tree, the time spent on delimbing it increases as well. 


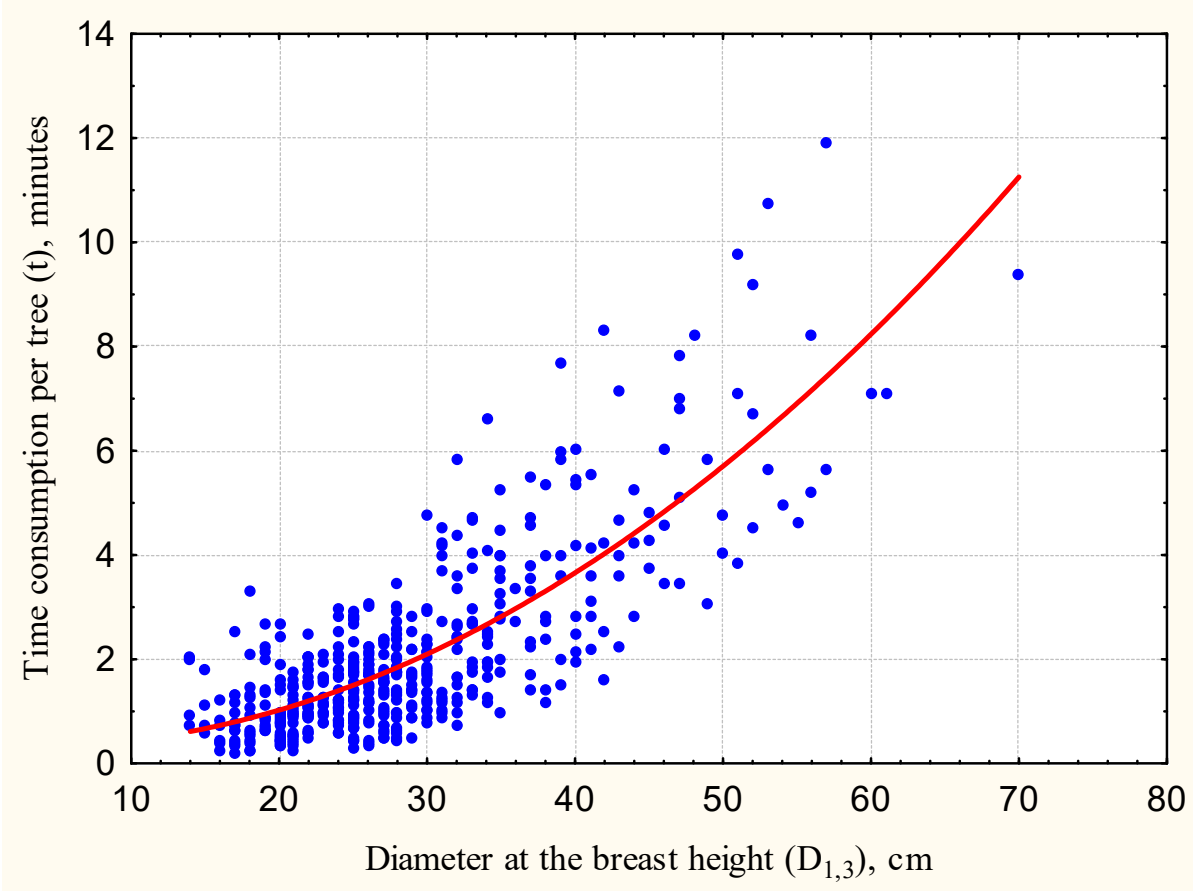

Graph 5. Time consumption of delimbing, minutes per tree

Grafikon 5. Utrošak radnog vremena za kresanje grana, minuta/stablu

\section{Forest residues management}

The analysis confirmed a statistical significant dependence between forest residues management and the breast diameter of a tree $\left(R^{2}=0,716\right)$. The dependence is also presented on Chart 6 , and the equation: $t_{\text {residues manag. }}=$ $4,8309-0,2932 \times D_{1,30}+0,0052 \times D_{1,30}{ }^{2}$. The chart shows that the increase in breast diameter influences the increase of time necessary for managing forest residues. 


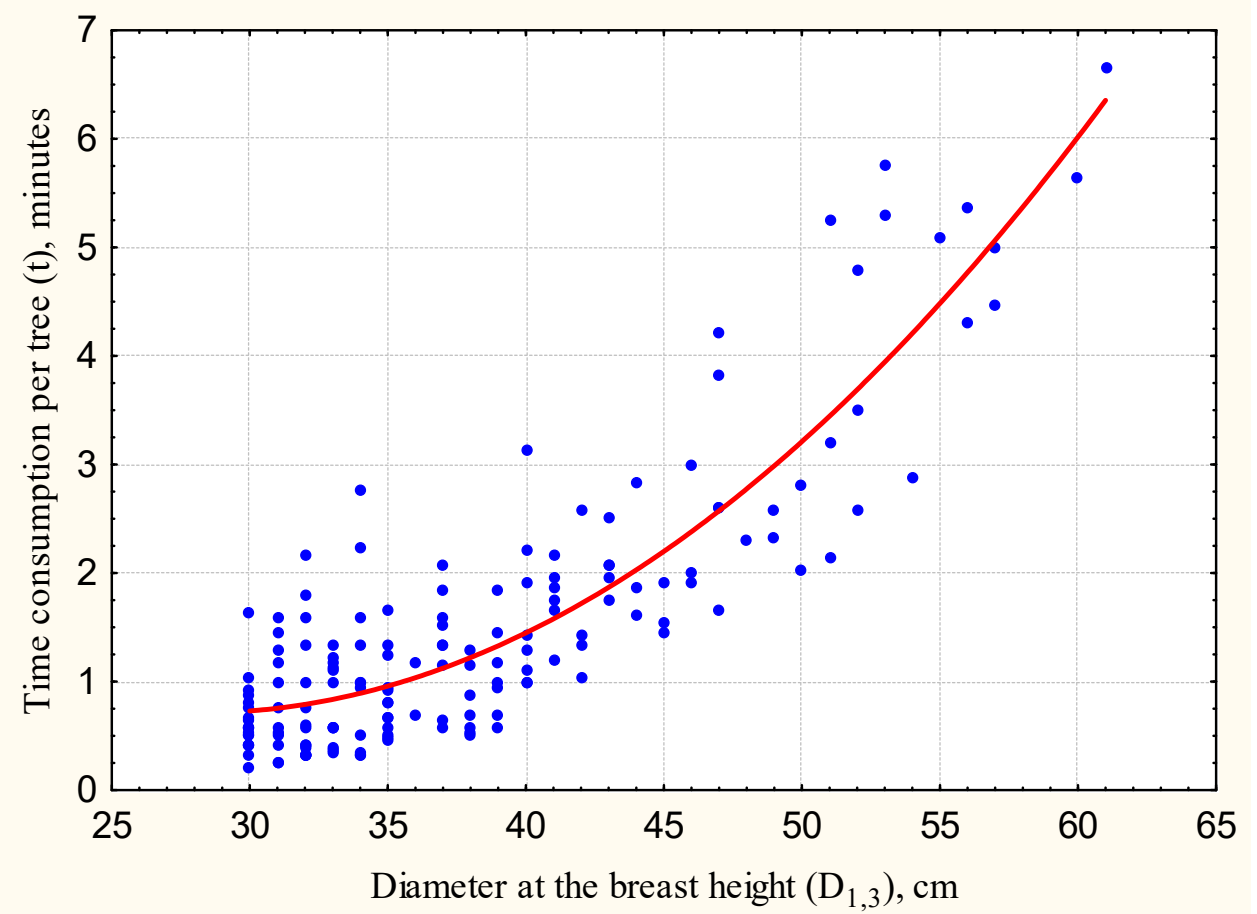

Graph 6. Time consumption of forest residues management, minutes per tree Grafikon 6. Utrošak radnog vremena za uspostavu šumskog reda, minuta/stablu

\section{Total time per tree}

The data on total tree time is presented in Chart 7, where the data is presented through a second-degree parabola: $\mathrm{t}_{\text {tree }}=0,2685+0,0159 \times D_{1,30}+0,0028 \times D_{1,30}{ }^{2}$, and the gained data show that the increase of tree diameter influences the increase of total effective time. 


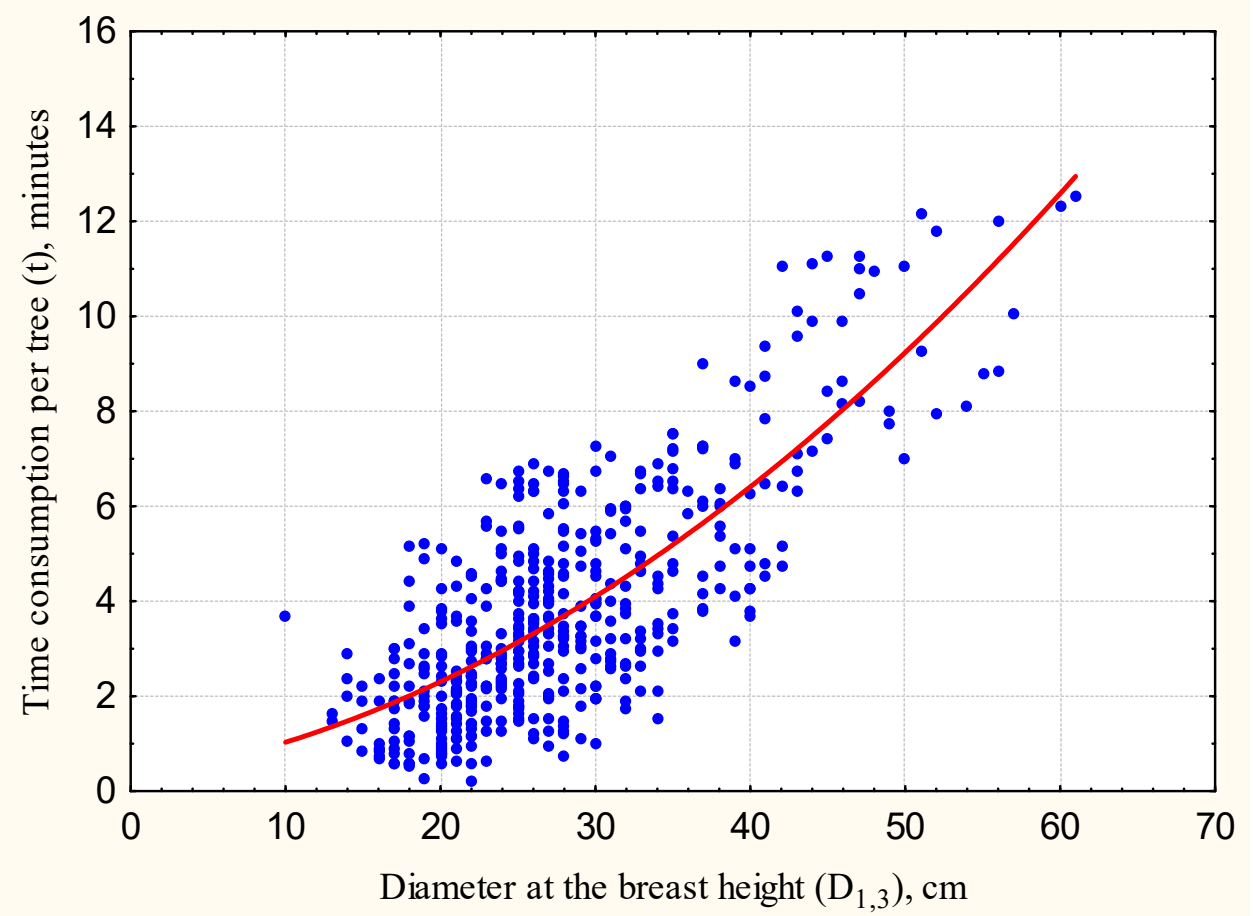

Graph 7. Effective time, minutes per tree

Grafikon 7. Operativno vrijeme, minuta/stablu

With the aim of comparison, a regression analysis was conducted of the dependency of total time per $\mathrm{m}^{3}$ of processed logs from felled trees, regarding the breast diameter of the tree, which is expressed in the following equation:

$\mathrm{t}_{\text {tree per }}{ }^{3}=27,5224-0,7213 \times D_{1,30}+0,0053 \times D_{1,30}{ }^{2}$.

The analysis confirmed statistical significant dependence of this parameter regarding the breast diameter of the tree $\left(R^{2}=0,656\right)$.

Based on the function, for the time spent per $\mathrm{m}^{3}$ of processed wood, the calculated values are presented in table 3 .

Table 3. Effective time, minutes per $\mathrm{m}^{3}$

Tabela 3. Operativno vrijeme, minuta $/ \mathrm{m}^{3}$

\begin{tabular}{|c|c|c|c|c|c|c|c|c|c|c|c|c|c|c|c|}
\hline $\begin{array}{c}\text { Diameter at the breast } \\
\text { height }\left(\mathrm{D}_{1,30}\right) \mathrm{cm}\end{array}$ & 10 & 15 & 20 & 25 & 30 & 35 & 40 & 45 & 50 & 55 & 60 & 65 & 70 & 75 & 80 \\
\hline $\begin{array}{c}\text { Time consumption }(\mathrm{t}) \\
\text { min. }\end{array}$ & 20.8 & 17.9 & 15.2 & 12.8 & 10.7 & 8.8 & 7.2 & 5.8 & 4.7 & 3.9 & 3.3 & 3.2 & 3.1 & 3.0 & 3.0 \\
\hline
\end{tabular}

The analysis of the data presented graphically (Chart 8), it is noticeable that the increase of breast diameter influences the decrease of time needed for producing 
assortments per volume unit. It can also be concluded that the curve suddenly drops to tree breast diameter of $60 \mathrm{~cm}$, only for the value to remain rather balanced later on.

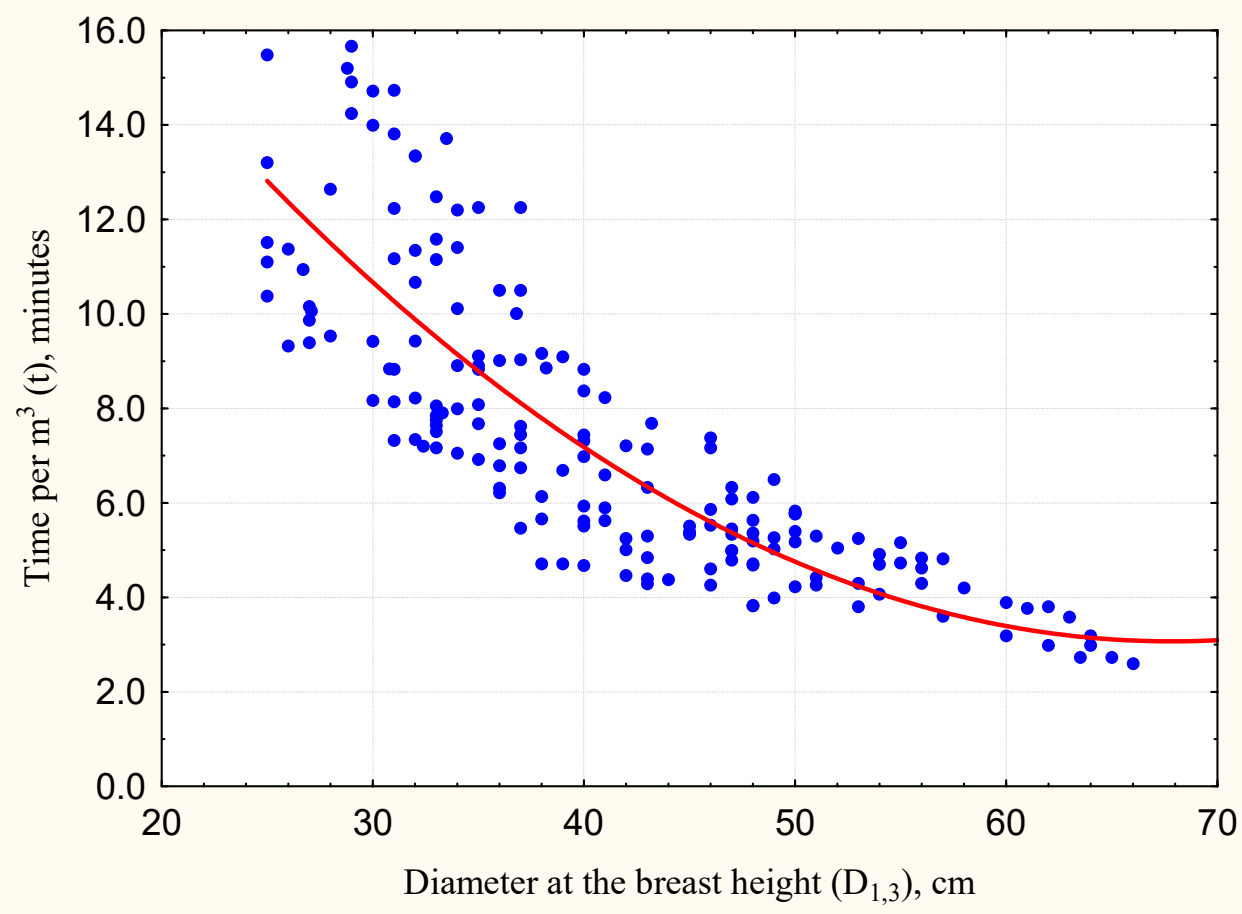

Graph 8. Effective time, minutes per $\mathrm{m}^{3}$

Grafikon 8. Operativno vrijeme, minuta $/ \mathrm{m}^{3}$

\section{Structure of time regarding interruptions in felling and sorting works}

Based on the recording time, there was a division of total working time to operational time and delay times. The structure of delay times is presented in the same manner as is the structure of operational time.

The percentage share of these times in the total time is presented in Table 4, and the percentage share of these times in the total delay time is presented in Chart 9. 
Analysis of time consumption during Sessile oak felling and processing works applying the fulllength method

Table 4. The share of delay times in total time

Tabela 4. Udio opštih vremena u ukupnom vremenu

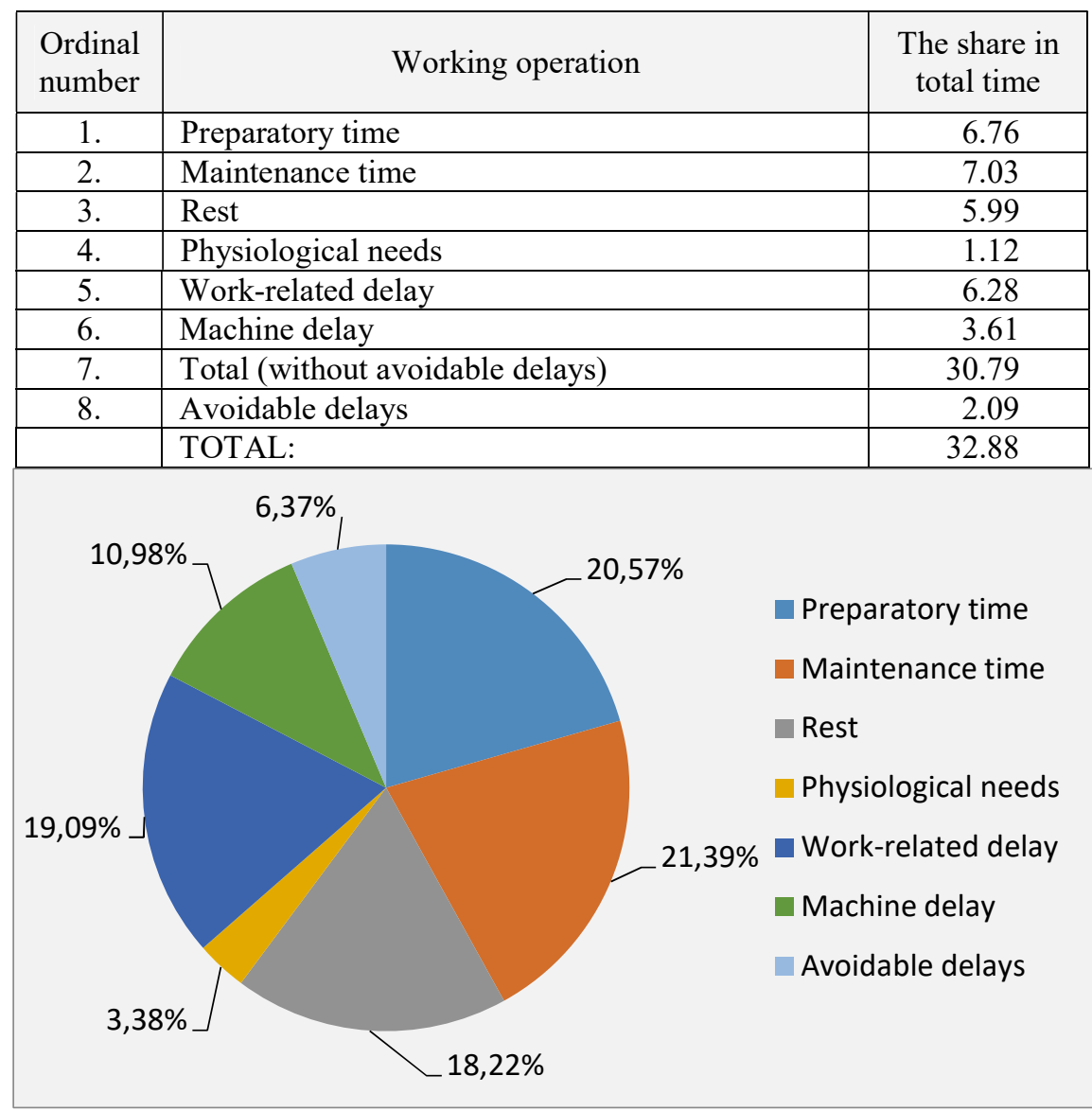

Chart 9. The structure of delay times

Grafikon 9. Struktura opštih vremena

\section{Preparatory time}

This time has a share of $6.76 \%$ in total time, and $20.57 \%$ in delay times.

\section{Maintenance time}

Registered maintenance times have a share of $7.03 \%$ in total time, with $21.39 \%$ in delay times.

Rest

In total time, rest time participates with $5.99 \%$, and $18.22 \%$ in delay times.

\section{Physiological needs}

The time spent on physiological needs is only $1.12 \%$ of total time, or $3.38 \%$ of delay times. 


\section{Work-related delay}

This type of delay participates with $6.28 \%$ in total time, and $19.09 \%$ in delay times.

\section{Machine delay}

Time spent on machine delay participates with $3.61 \%$ in total time, and $10.98 \%$ in delay times.

\section{Avoidable delays}

Avoidable delays participate with $2.09 \%$ in total time, and $6.37 \%$ in the structure of delay times.

\section{DISCUSSION - Diskusija}

The research of time consumption during felling and processing of Sessile oak by applying the full-length method has not been so thoroughly conducted in $\mathrm{BiH}$. This research ascertains the time consumption of working on the felling and processing of Sessile oak by applying the full-length method.

Detailed measurements of time consumption per individual operations in the phase of felling and processing using the chain saw presented data that show the participation of specific operations in this phase of work.

As part of the tree time, there is also the time for the preparation of the workplace, tree cutting, releasing lodged trees, delimbing and forest residues management.

Workplace preparation as a work operation participates with $3.75 \%$ in total time, and $5.59 \%$ in effective time.

Tree cutting as a work operation participates with $8.46 \%$ in total time, and $12.61 \%$ in effective time.

As can be seen in the structure of operational time, the time consumption for releasing lodged trees is $2.50 \%$ of total and $3.72 \%$ of effective time.

One of the highest participating phases in the process of felling and processing is the operation of delimbing. The share of this operation in total time was $31.78 \%$, and in the structure of operational time it was $47.35 \%$. In beech stand, conducting the similar methods MARČETA and KOŠIR (2016) established delimbing time of $33.73 \%$ of producing work time.

Following this operation is the forest residues management operation, which participates with $10.57 \%$ in total time, and $15.75 \%$ in the structure of effective time. By summing up the individual times, where an independently changing factor is the breast diameter of the tree, the total effective time per tree has been reached.

During the research, these values were at an interval of 15.2 minute $/ \mathrm{m}^{3}$ for breast diameter of $20 \mathrm{~cm}$ to 3.3 minute $/ \mathrm{m}^{3}$ for breast diameter of $60 \mathrm{~cm}$. This tree time can be used as means for comparison with the research of other authors.

Very useful research, especially for the purpose of comparison, was conducted by KULUŠIĆ and MIODRAGOVIĆ (1979). They researched the technological process of cutting, processing and extracting wood during the exploitation of pine and oak forests in $\mathrm{BiH}$. 
As part of the research of the mentioned authors, the total tree time for cutting was somewhat larger than this research and was between 17.07 minute $/ \mathrm{m}^{3}$ for breast diameter of $20 \mathrm{~cm}$ and 7.73 minute $/ \mathrm{m}^{3}$ for breast diameter of $60 \mathrm{~cm}$.

Somewhat larger values as compared to this research was presented by BOJANIN et al (1989). The tree time (minute $/ \mathrm{m}^{3}$ ) with these authors was between $18.64 \mathrm{minute} / \mathrm{m}^{3}$ for breast diameter of $20 \mathrm{~cm}$ and 11.81 minute $/ \mathrm{m}^{3}$ for breast diameter of $40 \mathrm{~cm}$.

If we compare the research in this paper with the research of BOJANIN and KRPAN (1994), we can conclude that the values of the tree times are lower. According to these authors, the time spent on felling and processing technical roundwood in the cutting phase for the Sessile oak was between 20.66 minute $/ \mathrm{m}^{3}$ for breast diameter of $22.5 \mathrm{~cm}$ and 12.73 minute $/ \mathrm{m}^{3}$ for breast diameter of $47.5 \mathrm{~cm}$.

The research by KOŠIR, (2005) demonstrates that correctly standardized times should serve as a guideline to different groups of subjects of forestry enterprises since those are the standard of normal work. The current state in forestry does not go in favor of the needs for more standardized times and their application, since economic effect can more easily be accomplished through lobbying, speculating etc. We are currently missing the incentive for new studies of work, even studies of checking work procedures in forestry.

We can conclude from all of this that the upcoming studies, the ones which are expected should include ergonomics, the economy of work procedures and environmental consequences of forestry work.

\section{CONCLUSIONS - Zaključci}

The following conclusions can be drawn based on the conducted research:

- In the felling and processing phase, 495 trees were cut. The breast diameter of the cut trees varied between 10 and $61 \mathrm{~cm}$. In the structure of the cut wood mass, technical wood participated with $52.57 \%$ or $201.23 \mathrm{~m}^{3}$, and fuelwood with $47.43 \%$ or $181.54 \mathrm{~m}^{3}$.

- In the total operational time structure of felling and processing, operational time participates with $67.12 \%$, delay times with $30.79 \%$, and avoidable delays with $2.09 \%$.

- Regarding the breast diameter of the tree, felling and processing is in significant correlation $\left(\mathrm{R}^{2}=0,656\right)$ which is proven with the following function:

$\mathrm{t}_{\text {tree per } m^{3}}=27,5224-0,7213 \times D_{1,30}+0,0053 \times D_{1,30}{ }^{2}$.

- Increasing the tree breast diameter, you decrease the time necessary for processing logs per volume unit.

- The selection of methods and means of work largely depend on the field and stand factors. The openness of an area is one of the most important factors 
which influence the application of a certain method of work in felling and processing.

- In that sense, it is important to remove the cause such as insufficient openness of these areas, and that a technical and technological solution is adjusted for each situation so that the final result is the most favorable, as seen from a breeding and economic aspect.

- All of this leads to the conclusion that when it comes to certain forestry enterprises, especially the ones with good technical equipment and openness of forests, the modified assortment method the so-called half-length method is largely present.

- Regardless of which basic technological model is to be applied, it is important to consistently respect technological discipline, otherwise there could be unfavorable effects.

- Considering the work conditions in $\mathrm{BiH}$, the application of the assortment method or its modified form still remains one of the solutions. Certain changes are expected with the introduction of new technologies in forest exploitation, and all those new circumstances require unceasing presence of competent staff in the area of forest works.

- This research is only one small portion in the wide issue of felling and processing trees.

\section{REFERENCES - Literatura}

BAJIĆ, V.(2003): Tehnika i tehnologija izvođenja seča pri različitim uzgojnim zahvatima u bukovim šumama, Udruženje šumarskih inženjera i tehničara Srbije i Šumarski fakultet, Šumarstvo 55 (1/2), str. 187 - 196.

BOJANIN, S.(1974): Primjena metode trenutačnih opažanja (MTO) za studij vremena kod obaranja i izrade jelovih stabala, Šumarski list 12, str. 483 - 504.

BOJANIN, S. (1978): Odnos utroška vremena i donje granice izrade sortimenata kod jelovih stabala, Šumarski list $11-12$, Zagreb, str. $439-457$.

BOJANIN, S., KRPAN, A. P. B., BEBER, J.(1989): Komparativno istraživanje sječe i izrade u prorednim sastojinama hrasta lužnjaka i crne johe, Šumarski list 113 (9/10), str. $591-602$.

BOJANIN, S., KRPAN, A. P. B.(1994): Eksploatacija šuma pri različitim radnim uvjetima u Hrvatskoj, Šumarski list 9 - 10, str. $271-282$.

BOJANIN, S., KRPAN, A. P. B.(1997): Mogućnost tzv. visokog i potpunog mehaniziranja sječe i izrade te mehaniziranja privlačenja drva u šumama Hrvatske, Šumarski list 121 (7/8), str. $371-381$.

DANILOVIĆ, M., OBUĆINA, Z.(2006): Komparacija troškova rada metoda seče i izrade šumskih sortimenata u zasadima topole, Traktori i pogonske mašine, br. 11, 3-4, str. $129-136$. 
HALILOVIĆ, V.(2012): Komparacija metoda dobivanja šumske biomase kao obnovljivog izvora energije iz hrastovih sastojina, Doktorski rad, Šumarski fakultet u Sarajevu, Sarajevo, str. $1-154$.

HALILOVIĆ, V., GURDA, S., SOKOLOVIĆ, DŽ., MUSIĆ, J., BAJRIĆ, M.(2013): Analiza utroška vremena pri sječi i izradi stabala hrasta kitnjaka primjenom sortimentnog metoda rada, Naše šume - Časopis za unapređenje šumarstva, hortikulture i očuvanja okoline, Sarajevo, br. $30-31$, str. $4-12$.

HÄBERLE, S. (1961): Die Multimomentaufnahme als Hilfsmittel für differenzierte Zeitbedarfsmessung, Forstarchiv, str. $73-75$.

JAVNO PREDUZEĆE ŠUMSKO - PRIVREDNO DRUŠTVO ZENIČKO DOBOJSKOG KANTONA D.O.O ZAVIDOVIĆl (2006): Cjenovnik radova u šumarstvu, Sječa, izrada i izvoz drvnih sortimenata kao i drugih faza rada, Zavidovići.

JOVANOVIĆ, B. (1980): Istraživanje utroška vremena za dvije tehnologije rada kod eksploatacije bukovih šuma u SR BiH, Magistarski rad, Šumarski fakultet Sveučilišta u Zagrebu, Zagreb, 1980. str. 1 - 248.

KOŠIR, B. (2005): Studij rada - je li to zaboravljena znanstvena grana u šumarstvu?, Mehanizacija šumarstva 2001 - 2004., Posebno izdanje časopisa Nova mehanizacija šumarstva, br.1, str. $17-21$.

KRALJIĆ, B.(1974): Problematika prikladnosti i ekonomičnosti snimanja multimomentnom metodom u šumarstvu, Šumarski list 12, str. $475-482$.

KULUŠIĆ, B.(1977): Istraživanje tehnološkog procesa sječe i zrade drvnih sortimenata u čistim bukovim šumama i mješovitim šumama buve, jele i smrče u SRBiH, Radovi Šumarskog fakulteta i Instituta za šumarstvo u Sarajevu, Sarajevo, Knjiga 21, Sveska $1-2$, str. $99-154$.

KULUŠIĆ, B., MIODRAGOVIĆ, D.(1979): Prilog istraživanja tehnološkog procesa sječe, izrade i privlačenja drveta pri iskorišćavanju borovih i hrastovih šuma u $\mathrm{BiH}$, Radovi Šumarskog fakulteta u Sarajevu, Sarajevo, Knjiga 22, Sveska 5 - 6, str. $3-66$.

MARČETA, D., KOŠIR, B. (2016): Comparison of Two Felling \& Processing Methods in Beech Forests, Croatian Journal of Forest Engineering: Journal for Theory and Application of Forestry Engineering, 37(1), 163-174.

TOMANIĆ, S. (1975): Komparativna studija vremena kronografskom i multimomentnom metodom pri sječi i izradi drva, Šumarski list $1-3$, str. $9-22$.

ZEČIĆ, Ž., PORŠINSKY, T., ŠUŠNJAR, M.(2004): Neki rezultati eksploatacije brdskih sastojina skupnim radom uz osvrt na izbor metode studija vremena, Šumarski list $7-8$, str. $381-389$. 


\section{SAŽETAK}

U ovom radu prikazana je analiza primjene deblovne metode $u$ fazi sječe i izrade hrasta kitnjaka.

Cilj istraživanja je bio utvrditi utroške vremena rada na sječi i izradi stabala hrasta kitanjaka primjenom deblovnog metoda rada PJ „Šumarija“ Olovo, G.J. „Krivaja“, odjeljenje 112.

U sklopu istraživanja ukupno je posječeno 495 stabala hrasta kitnjaka, a ukupna zapremina je iznosila $382,77 \mathrm{~m}^{3}$.

Kod mjerenja utroška vremena rada po pojedinim operacijama primijenjen je trenutačni metod opažanja, sa intervalom opažanja od 20 sekundi. Organizacija sječe je bila $1+1$ (sjekač i pratioc).

Provedenom analizom je ustanovljeno da u strukturi ukupnog radnog vremena sječe i izrade čisto (operativno) vrijeme participira sa $67,12 \%$, opća vremena sa $30,79 \%$, a neopravdani prekidi sa $2,09 \%$.

U okviru stablovnog vremena su vremena pripreme radnog mjesta, rušenje stabla, ustave stabla, kresanje grana i uspostava šumskog reda.

Priprema radnog mjesta kao radna operacija u ukupnom vremenu učestvuje sa 3,75\%, dok u čistom vremenu njeno učešće je 5,59\%.

Rušenje stabla kao faza rada u ukupnom vremenu učestvuje sa $8,46 \%$, dok u čistom vremenu participira sa $12,61 \%$.

Kako se vidi iz strukture čistog (operativnog) vremena, utrošak vremena ustava čini $2,50 \%$ ukupnog i $3,72 \%$ čistog vremena.

Jedna od faza rada koja najviše participira u procesu sječe i izrade drveta je radna operacija kresanja grana. Vrijednost ove radne operacije u ukupnom vremenu je iznosila $31,78 \%$, dok ta vrijednost u strukturi operativnog (čistog) vremena je iznosila $47,35 \%$.

Nakon ove radne operacije u samoj fazi slijeda događaja je uspostava šumskog reda gdje je ova faza rada participirala u ukupnom vremenu sa $10,57 \%$, a dok je u strukturi čistih vremena ta vrijednost iznosila $15,75 \%$.

Istraživanje pokazuje jaku korelacionu vezu sječe i izrade stabala u odnosu na prsni promjer stabla $\left(\mathrm{R}^{2}=0,656\right)$.

Iz analize podataka može se vidjeti da se sa povećanjem prsnog promjera stabla smanjuje vrijeme neophodno za izradu debala po jedinici zapremine.

Trenutno nedostaje poticajnost za novim studijama rada, pa čak i studijama provjere radnih postupaka u šumarstvu. Međutim, istraživanja koja se mogu očekivati u narednom periodu trebala bi svakako uključiti ergonomiju, ekonomiju radnih postupaka, sigurnost na radu i ekološke posljedice šumskoga rada.

Corresponding author: Velid Halilović; Faculty of Forestry University Sarajevo; Zagrebačka 20, $71000 \quad$ Sarajevo, Bosna\&Herzegovina; e-mail address: v.halilovic@sfsa.unsa.ba 